\title{
A Framework for Evaluating Citizens' Expectations and Satisfaction toward Continued Intention to Use E-Government Services
}

\author{
Mubarak Alruwaie, Ramzi El-Haddadeh, and Vishanth Weerakkody \\ Brunel University, Brunel Business School \\ Uxbridge, Middlesex, UB8 3PH United Kingdom (UK) \\ \{mubarak.alruwaie, ramzi.el-haddadeh, \\ vishanth.weerakkody\} @brunel.ac.uk \\ http: / /www. brunel.ac.uk
}

\begin{abstract}
This paper examines the role of expectation and satisfaction in influencing citizens' intention to continue using electronic government services. In order to investigate the key factors that affect an individual's use of Information and Communication Technology within the context of electronic government, a framework combining Social Cognitive Theory and ExpectationConfirmation Theory is used to investigate satisfaction and continuity of use of e-government services. Further, the study incorporates DeLone and McLean's IS success model along with the E-S-QUAL model to incorporate technical, organizational and Information Systems quality into this framework. The proposed framework will help in shaping further studies in cognitive, managerial and technical factors related to e-government adoption and use. This study argues that quality and consistency in e-government services affect the expectations and satisfaction of citizens, therefore impacting on its continuity of use.
\end{abstract}

Keywords: E-Government, Use, Continuity, Expectation, Satisfaction.

\section{$1 \quad$ Introduction}

In recent decades, the topic of electronic government (e-government) has been the subject of much debate within the research community [1]. Since the emergence of egovernment in the late 1990s, the public sector has invested heavily in Information and Communication Technology (ICT) to support their work processes and e-enable their services. However, with the increasing use of e-commerce in the private sector, citizens have become more experienced in the use of electronic services, thus expecting a similarly high standard of service quality from government agencies. Yet, the literature suggests that individuals' performance vary based on their self-efficacy and therefore have different expectations [2]. Bandura [3] argues that the advancements in ICT and associated social developments have had a considerable influence on personal efficacy for self-development. In e-government, the purpose is to improve service delivery to all stakeholders [4] but research suggests that the 
potential of e-government services and enabling IT applications are underutilized [5]. This has forced government organizations to change their current technologies or to adopt other strategies that combine multi-channels for e-government service delivery [6]. Consistency or harmony between e-government services and citizens' behaviour is crucial toward utilising these services, and then to continue to use them. These notions of cognition have been discussed previously by scholars who have employed similar constructs in order to explain the acceptance, continuity and utilization of ICT [7][8][9].

E-government is evolving toward more sophisticated and complex systems of rules and standards [10]. Public sector managers are looking for solutions to optimize services but at the same time, citizens and other stakeholders are looking for better services; they are influencing the evolution of e-governance and the quality of services through their previous experience. These two varying perspectives will establish new expectation and satisfaction levels as well as associated behavioural patterns [2]. Coiera [11] emphasised the role of interaction between human and computational agents, concluding that the characteristics of individual technologies and psychological/social issues can be combined to explain the overall decisions that individuals make when using technology. Thus, the interaction between users (cognitive factors) and their social, technological and organisational environment (environmental factors) plays an important role in the continuous use of e-government systems.

The challenge that government faces is the question of how to maintain and continuously improve satisfaction and expectations among citizens, and match the provided e-government services with their level of skills'. Some researchers have noted that user satisfaction, rather than behavioural intention, is a more appropriate dependent variable in mandated use environments [12][13][14][15]. There is a need for highly appropriate measures for evaluating the success of new information systems (IS) and their links with user satisfaction [16] but in an e-government context, we argue that satisfaction with technology alone does not wholly explain the interaction between citizens and government in practice. Bandura [2] emphasizes the role of self-efficacy; this is the process whereby users regulate their behaviour based on what they can or cannot do, according to their self-evaluated ability and reactions; having skills related to particular actions or needs is critical for effectively utilizing egovernment. However, any lack of access to e-government services could widen the gaps between the different socio-economic levels and hinder citizens from gaining the full benefits of e-services [17][5][18]. As an inference from this, "organisations may be able to achieve considerable economic benefits (via relatively low incremental investment) by successfully inducing and enabling users to (appropriately) enrich their use of already-installed IT-enabled work systems during the post-adoption stage" [6], i.e. government departments may need to consider how to encourage potential users to utilize existing systems.

There has been little research on assessing the processes through which the quality of services provided by government are influenced by previous experiences and selfefficacy, and how the quality of services can influence the continuity-of-use perceptions of citizens (i.e. satisfaction and expectation vis-à-vis continuing to use egovernment services). However, the issue has been briefly touched upon by various authors, e.g. [2][7] [8][14][19][20-24], who argue that citizens with positive 
expectation are more likely to be involved in using e-government services, and that this could lead to an improvement in e-government practice and in the relationship between citizen and government in both the short and long term, although a detailed framework for assessing this has not been fully addressed. Accordingly, the aim of this study is to develop a research framework for evaluating citizens' expectations towards the continuous use of e-government services. Through analysing the literature on e-governance adoption as well as IS service quality models, we shall develop a conceptual framework that emphasizes the relationship between the organisation (government) and the end users (citizens). Limited research has been conducted to fully comprehend citizens' motivations to adopt and continuously use e-government services, and there is a lack of comprehensive models that take into consideration the expectations of the service provider (government) and service user (citizen) with respect to their behavioural intentions [25]. Salient personal cognitive, social and organisational factors that determine citizens' continued use of e-government services will be identified in this study. We argue that personal expectation perspectives offer a novel and relevant lens in order to appraise citizens' acceptance behaviour toward e-government use. In order to pursue the above, this paper is structured as follows: Section 2 offers a literature review of relevant theoretical models for studying user satisfaction. Section 3 introduces a conceptual framework for examining user satisfaction. Section 4 discusses the key factors that influence continuous intention to use e-government services. The paper concludes in Section 5 by summarizing the key contributions of the study.

\section{Theoretical Background}

E-governance is targeted at all citizens but it is difficult to satisfy the whole population. This is unlike private sector e-business services, where segmentation can be easily defined. If people are less than satisfied with the current services, they are unlikely to revisit or to recommend others to visit government websites [27]. Such behaviour could help to explain the variations in perception or cognition as well as skills while participating in e-governance [29][30]. However, there is limited research in the e-government domain that examines the impact of user satisfaction on continuous use. From a marketing perspective, Kotler et al. [31]considered ICT as a tool for integrating the social environment, citizens and organisations, through which entities can compete by utilising the Internet. Yet, hat research focused on groups or segmented markets to evaluate the impact of marketing and awareness strategies on satisfaction, whereas e-government is targeting the whole population. In an egovernment context, Reffat [32] posits that the apparent lack of marketing strategies to raise awareness may act as a barrier to the adoption of e-government services. Further, Gilbert and Balestrini [10] conducted a study on the same issue based on attitudinal aspects of technology adoption and related service quality impacts. They found that while trust, financial security, relevance, and accurate and updated information represent major barriers, time and cost are the most important benefits that entice citizens to use e-government services. They identified three main 
approaches that have theoretical and empirical bases with respect to ICT adoption and use: 1) the Diffusion of Innovation (DOI) theory and model (explained by [33]); 2) the Technology Adoption Model (TAM) (explained by [34]) and the Theory of Reasoned Action (TRA) (explained by [35]); and 3) Service Quality. All of these can be exploited to explain the variations in the levels of e-government use, from basic one-way communication up to interactive transactional services [4].

In light of the above, many governments have tried to improve the quality of their e-services by strengthening mutual trust. In this respect, e-governance is seen as a mechanism for agencies to reduce the cost and time for citizens by improving efficiency and effectiveness [29], rather than as a mechanism for cost-cutting. Almost all governments in developed and developing countries have established official e-government portals offering online services [27]. Nonetheless, if e-government services do not match the citizens' expectations, it is unlikely that they will continue to utilise them 28. According to the Diffusion of Innovation Theory [33], relative advantage, or how the user perceives the value of the innovation based on his/her past experiences and needs, is a major factor influencing the rate of diffusion. Moore and Benbasat [36], however, consider image as a significant motivator of use. Other studies have also considered social influence as an important factor [37]. Also, theories on social influence (or subjective norms) have been incorporated into models (e.g. UTAUT). Such models emphasize the role of personal perceptions in terms of peer influence on behaviour [38]; social influence cannot be ignored in e-government practice.

Besides the social theme, many other factors may influence e-government practice, for example, self-interest or expectations (as the cognitive influence of a particular action and its advantageous consequences) [2]. Further, satisfaction as an attitudinal influence is considered key in marketing studies [31], where it is used by the customer to measure the delivery of a product. However, here we consider the e-government context, and the focus is on evaluating satisfaction based on service delivery. In the same vein, Zeithaml [23] and Parasuraman, Zeithaml and Malhotra [42] discussed the gap between expected services (outcome expectation) and perceived services (satisfaction) in the SERVQUAL model. That study considered this gap from a citizen-centric point of view with respect to how public agencies deliver e-government services.

\subsection{Prior Research on IT Usage}

The literature on IS research suggests that the stream of technology adoption (on the individual level) has reached maturity [43]. In this regard, Chan et al. [15] suggest that pre-usage beliefs may serve as anchors for post-usage beliefs, as people tend to rely on their initial beliefs and early impressions in the formation of future beliefs. Hence, there may be two major barriers to adopting and continuing to use technology. A number of theoretical models have been proposed in technology adoption studies. TAM and its major determinants 'perceived usefulness' and 'ease of use' [34] together with adaptations of the TRA have been the two dominant models in previous research in IS. Further, the Theory of Planned Behaviour (TPB) and UTAUT have been heavily used in previous IS studies (e.g., [14][15][19][35][38][44] ). 
Many previous studies have examined the effects of user belief and attitude on IT usage intention and behaviour [19][47]. In this respect, several theoretical models have been employed, combining IS with psychology and sociology, where researchers have selected constructs from certain models while leaving out the contributions of others [19]. For instance, the UTAUT model has eight different models integrated within it [TRA, Combined TAM and TPB (C-TAM-TPB), motivational model, TPB, Model of PC Utilisation (MPCU), Innovation Diffusion Theory (IDT), and SCT]. Therefore, UTAUT has also integrated some of those models' limitations. Significantly, post-adoptive-behaviour and variables such as satisfaction and personal outcome expectations towards continuous usage of IS have not been considered. Therefore, we posit that an extended model is needed to examine the continuity of IS use. This is particularly relevant for e-government information systems, given the number of studies that have identified the significance of satisfaction towards continued intention to use e-government services (e.g., [15][14][5]). Hence, reviewing and synthesizing the relevant theoretical models in IS adoption is crucial for understanding continuity in e-government use.

Many previous IS adoption models have focused on understanding the usage of technology at the individual level and the implementation success at an organisational level, mainly in the private sector or in commercial settings. For example, while researchers such as Venkatesh et al. [19] and Bhattacherjee [48] focused on the private sector, users in this environment are significantly different to those in the egovernment context. Moreover, these studies did not examine the post-adoptive stage (i.e. continuity of use), and in fact [15] argued that there is a need for technology acceptance studies that link pre-usage with post-use behaviour (in other words, studies that focus on continuity of use) particularly in e-governance. Further, there is also a need to consider the impact of motivation on continuing to use it [49]. A motivational model is incorporated in UTAUT but it does not explicitly examine the intrinsic motivational factor with respect to personal expectation, and therefore, citizens' internal constraints, such as personal expectations, are not considered (see [7]). As such, UTAUT leaves a gap in relation to understanding citizens' personal outcome expectations towards e-government use. For instance, Layne and Lee [4] mentioned speed and cost as important features of e-government services; these are crucial for citizens in an e-government context, but not for employees who work in public organisations because they are more likely to be motivated by job prospects or salary. Hence, from a citizen's perspective, self-efficacy forms part of personal outcome expectation as an intrinsic motive [2] in an e-government context. In addition, Bandura states that both anticipated satisfaction and the negative appraisals of insufficient performance provide incentives for action. He also suggests that when individuals accomplish a given level of performance, they are often no longer satisfied with the service and make further self-reward contingent on higher attainments. Therefore, citizens' action and behaviour are driven by self-interest, which is influenced by self-efficacy [2][21].

\subsection{Expectation-Confirmation Theory (ECT)}

When focusing on the diffusion and adoption of IT applications, three high-level stages are important: pre-adoption, adoption and post-adoption [33]. The ECT model is widely 
used in the study of user satisfaction (e.g. [8][15]) and post-purchase behaviour, and holds that users' intention to reuse the system as a service is determined primarily by their satisfaction with prior use of that service [51]. Bhattacherjee [24] adopted ECT to further comprehend IS continuance use, and looked at continuance as an extension of acceptance behaviour; he addressed post-adoptive behaviour in online banking. Those results support ECT's contention that satisfaction with IS use is the strongest predictor of continuance intention. The model examined pre- and post-behaviour to verify the variation between what is expected and actual performance, so that an indicator can be perceived to decide repurchase intentions. Based on Hsu et al. [8], ECT was extended by integrating it with SCT to examine the motivational factors that influence one's intention to continue using Internet applications. They found that there are variances between continuity of using the Internet, outcome expectation and satisfaction. Such findings suggest that in the e-government realm, it is crucial to understand the factors that influence citizens' behaviour to continue using online services provided by public agencies. Moreover, satisfaction can be used as an evaluation process to measure citizen's perception of the e-government services. However, there are some limitations to the use of ECT; it ignores the potential change in initial expectations and consequent cognitive process variables [48].

Previous studies have found that ECT is based on extrinsic motivations rather than both extrinsic and intrinsic [49] but it can assess extrinsic motivation in the form of satisfaction as an attitudinal influence towards continuity in using e-government services. Similarly, SCT can assess intrinsic motivation in the form of personal outcome expectation to represent personal cognitive beliefs. Relative to SCT, in the relations between the three determinants of a triadic reciprocal causation model (Figure 1), ECT better fits the study of e-government use satisfaction, using satisfaction as the measurement of an event and using behaviour as a continuance intention to using e-government services. By integrating ECT into SCT, the intrinsic motivational factor is seen in SCT as the personal cognitive factors (personal outcome expectations). Further, Bandura [2] and Compeau and Higgins [52] argue that it is essential for a decision maker to consider both intrinsic and extrinsic motivational factors when examining satisfaction. Thus, we propose the use of SCT as the basis of our framework to study use and satisfaction in e-government systems.

\subsection{Social Cognitive Theory (SCT)}

As a well-accepted model of individual behaviour, SCT has been used to evaluate performance in various service domains [53]. SCT highlights the role of personal interaction with an external event and how this interaction introduces new behaviour. According to Verdegem et al. [54], users' perceptions of the e-services offered are crucial. The strong relationship between contextual variables and satisfaction requires that the use aspects (citizens' side), rather than the government (service provider side), are focused upon when evaluating e-government services. Hence, the role of users (citizens) is crucial in order to gain a better measurement of satisfaction.

The relationship between government and citizens cannot be examined without action on the part of the citizen. In this respect, SCT holds, "outcome expectations about the consequences of behaviour are a strong force guiding individuals" actions" 
[7]. Expectancy is perceptually a catalyst of human motivation, as it is the perception that one's efforts will possibly result in the achievement of the desired task, which is rooted in an individual's past experience, self-efficacy, and the perceived difficulty of the assigned task [55]. Therefore, reward (in achieving the task) based on personal outcome expectation is seen as accomplishment (intrinsic), more than social recognition or promotion (extrinsic) [9]. This argument is further extended by Wasko and Faraj [56], who emphasised the role of expectation of personal benefits in terms of individual motivation. Those authors posited, "[i]n the social cognitive view, people are neither driven by inner forces nor automatically shaped and controlled by external stimuli. Rather, human functioning is explained in terms of a model of triadic reciprocality in which behaviour, cognitive and other personal factors, and environmental events all operate as interacting determinants of each other."

Prior research also indicates that users are more likely to execute tasks that are similar to those performed by their peers [20][2]. This is often achieved by rehearsing action and learning from past experience in the same social context (ibid). Bandura [20][2] stressed that "weak expectations are easily extinguishable by disconfirming experiences, whereas individuals who possess strong expectations of mastery will persevere in their coping efforts despite disconfirming experience". These arguments would lead that author to discard the construct in ECT of confirming/disconfirming prior experience, replacing it with outcome expectations. For that reason, the authors here use prior experience as a generic construct. On the other hand, in SCT a continuous reciprocal causation among environmental factors, cognitive factors, and human behaviour factors exists that cannot be discarded [8][2]. Therefore, prior use of an IT application is already situated within a stream of use experiences even if it has not occurred [6]. Carter and Bélanger [57] found compatibility of the system to be the most significant factor; hence, if people expect the same benefits from e-government services as they gain from using the Internet for online shopping, they are more likely to adopt e-government systems. Thus, prior experience is a crucial factor, one that influences the post-adoptive stage. The user-oriented approach suggests that in order to measure user satisfaction vis-à-vis e-government services, citizens' needs and expectations towards e-government services are essential considerations [58].

The social theme in e-government practice is critical, as the media, friends, family and co-workers all have an influence on each citizen's awareness and level of confidence [35]. Lack of awareness is a barrier to e-government practise [32]. Zeithaml et al. [58] emphasized the role of advertisement in increasing the level of awareness among citizens in e-government projects. Rogers[28] mentioned that middle management, top management and politicians have low IT skills, caused by lack of awareness at the first level, and therefore, citizens are expected to experience the same or less. According to SCT and the Compeau and Higgins [7] model, behavioural modelling (social influence) engages self-efficacy; by observing others, people can learn new behaviour, subject to their ability and previous experience [22][2]. According to the Diffusion of Innovation model [58], users can be categorised into five groups: innovators, early adopters, early majority, late majority and laggards. Perhaps not surprisingly, the percentage of innovators represents only 
$2.5 \%$; they can however act as a role model, giving others the opportunity to observe and oversee the outcomes of using e-government.

\section{Research Framework}

This paper is stimulated and informed by the contributions of the above theories and models, more specifically SCT [2][52], ECT [24][8], the IS success model [16] and E-S-QUAL [42]. Those models have been widely used, however, they are less used in the field of e-government in developing countries with respect to citizens' points of view. Therefore, this study has considered the many and various previous studies [19]; it has not ignored their contribution, indeed it adds credit to their efforts. Accordingly, Table 1 presents the proposed factors (derived from the literature), which have assisted in formulating the proposed framework of this study, relating to continuance intentions vis-à-vis e-government services (see Figure 1).

Table 1. Factors Employed in Existing Studies to examine continuance intention

\begin{tabular}{|c|c|c|c|}
\hline Constructs & Description & $\begin{array}{l}\text { Theory/ } \\
\text { model }\end{array}$ & Sources \\
\hline $\begin{array}{l}\text { Personal Outcome } \\
\text { Expectations } \\
\text { (POE) }\end{array}$ & $\begin{array}{l}\text { "Is a person's estimate that a given } \\
\text { behaviour will lead to certain } \\
\text { outcome." Or "a judgment of the likely } \\
\text { consequence such performances will } \\
\text { produce." }\end{array}$ & SCT & {$[2][3][7][52]$} \\
\hline Self-Efficacy (SE) & $\begin{array}{l}\text { "An individual's perception of efficacy } \\
\text { in performing specific computer- } \\
\text { related tasks within the domain of } \\
\text { general computing." }\end{array}$ & SCT & $\begin{array}{l}{[2][3][7][20][21]} \\
{[22][52][57][63]}\end{array}$ \\
\hline $\begin{array}{l}\text { Prior Experience } \\
(\mathrm{PE})\end{array}$ & $\begin{array}{l}\text { Bandura refers to prior experience as } \\
\text { enactive mastery, which is information } \\
\text { based on "authentic mastery } \\
\text { experiences", or past experience in } \\
\text { performing tasks according to their } \\
\text { expectations. }\end{array}$ & $\begin{array}{l}\mathrm{SCT} / \\
\mathrm{ECT}\end{array}$ & $\begin{array}{l}{[2][3][7][22][24]} \\
{[47][48][50][52]}\end{array}$ \\
\hline Satisfaction (SAT) & $\begin{array}{l}\text { Users' feelings about prior } \mathrm{e}- \\
\text { government services use. }\end{array}$ & $\begin{array}{l}\mathrm{ECT} / \\
\mathrm{D} \& \mathrm{M}\end{array}$ & $\begin{array}{l}{[8][14][15][24]} \\
{[47][48][50]}\end{array}$ \\
\hline $\begin{array}{ll}\text { IS } & \text { Continuance } \\
\text { (IC) } & \\
\end{array}$ & $\begin{array}{l}\text { Users' intention to continue using e- } \\
\text { government services. }\end{array}$ & ECT & {$[24][47][48][50]$} \\
\hline $\begin{array}{l}\text { Information } \\
\text { Quality (IQ) }\end{array}$ & $\begin{array}{l}\text { Information quality reflects the } \\
\text { degrees of personalization, relevance, } \\
\text { completeness and ease-of- } \\
\text { comprehension. }\end{array}$ & D \&M & {$[16][61]$} \\
\hline $\begin{array}{l}\text { Service Quality } \\
\text { (SQ) }\end{array}$ & $\begin{array}{l}\text { One's judgment about a product's } \\
\text { services taken as a whole, or the } \\
\text { difference between service delivered } \\
\text { and customer expectation. }\end{array}$ & $\begin{array}{l}\text { D \&M } \\
\text { /SERV } \\
\text { QUAL/ } \\
\text { E-S- } \\
\text { QUAL }\end{array}$ & $\begin{array}{l}{[23][16][31][42]} \\
{[59][60][62]}\end{array}$ \\
\hline $\begin{array}{l}\text { Social Influence } \\
\text { (SI) }\end{array}$ & $\begin{array}{l}\text { The degree to which peers influence } \\
\text { the use of the system, whether positive } \\
\text { or negative. }\end{array}$ & SCT & $\begin{array}{l}{[2][3][14][15]} \\
{[41][45][46][63]}\end{array}$ \\
\hline
\end{tabular}


The proposed framework underpinning this study is based on SCT, ECT and DeLone and McLean's IS success model as well as other acceptance factors (as used in UTAUT). The presented research addresses post-adoptive behaviour, which has already been modelled and influenced by factors that lead to acceptance and initial use [6]. Figure 1 illustrates the proposed framework of this study.

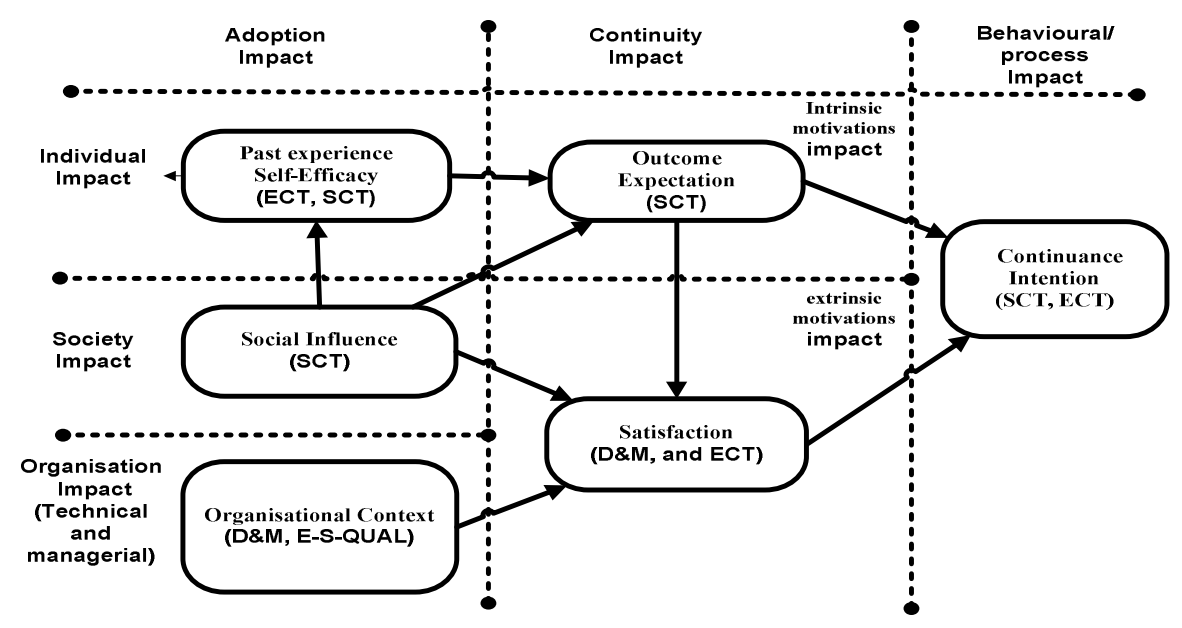

Fig. 1. The proposed framework

\section{Discussion}

Drawing on SCT, there are three major scopes that should be taken into consideration in predicting one's action toward a future perspective: personal factors, environmental factors and behavioural factors. Hence, linking past experience and self-efficacy with one's outcome expectation is crucial in order to broaden one's capacity through gaining the required skills, which then act as a driver for any potential or required action toward e-government services. However, the interests of a typical working citizen are different to those of one not working; the average non-working citizen is looking for cheaper and faster services, rather job promotion. Hence, the estimations of their outcome expectations require different approaches. The non-working citizen is not motivated by punishment and reward in the working environment while performing the task, which affords them more alternatives in selecting an e-service. Therefore, it is the e-service organisation's responsibility to stimulate the citizen's interest into interacting with e-government, and this can be achieved in three stages: the adoption stage, the continuity stage and the behavioural stage, as in the following three paragraphs.

Firstly, the adoption stage contains three phases: technical and managerial impact (organisational impact), social impact and individual impact. This is the external stimulus interaction that the environmental factor has on the personal factors, based on SCT. As noted from the model, the organisation, society, prior experience and 
self-efficacy all indirectly influence the desired continuance behaviour, and it will not come to pass through without satisfaction or the sum of the personal outcome expectations of the citizen as a core of the process. Therefore, and in order to reach the required behaviour, an organisation should focus on the marketing impact, such as awareness, and highlight the role of skills, based on experience and self-efficacy, word of mouth and social impact in order to strengthen the function of satisfaction. However, there are marketing regulations, one may not sell a product (services or goods) that does not exist, and therefore, tangibility (system and information) and intangibility (services) should exist to ensure the availability of the product. Thus, the first step an organisation should start with is managerial impact and technical impact, by establishing the required ICT-related issues (e.g. system, infrastructure, network and other hardware as well as software, etc.); in other words, the implementation and awareness processes as well as the support of social influence (society's impact). There should a managerial plan for managerial impact and technical impact that is in line with the capability of the targeted user, correlated with a proper marketing plan. This would help in fully utilising the invested budget. Hence, a strong relationship is required between decision makers at all levels and the citizens' demands.

Secondly, the continuity impact; this stage depends upon the acceptance variables in the adoption impact, where there may be some debate over precisely which variable is needed, based on the evolution process in each society or country. In this stage, the citizen is the only one who can translate acceptance into a continuance process. The cycle of the process, through learning from past experience, will shape the course of action when dealing with a repeat procedure in e-government practice, making it easier the next time. Thus, the awareness marketing impact, conducted through media or relatives, friends and co-workers can be considered as modelling, as noted by [2] and vicarious experience. Experiencing the e-government services will make it easy to identify the weaknesses in one's personal factor (cognitive); this should then act as a driver for further enhancement in building self-efficacy. However, without continual use of the system, it would be difficult to cope with software advances or up-to-date issues. Therefore, escalating self-efficacy to the required task in the process, supported by past experience and social influence, will enhance personal outcome expectation (personal, not job in this study) by ensuring the citizen that he or she can implement and function within the services offered. As a result, the satisfaction level toward the e-services will increase as long as there is a feeling that personal skills are developing.

Thirdly, the behavioural impact; this stage is the output of how citizens perceive the delivered services, and it involves the relationship between the personal factors and the environment (social and organisational) factors. If a citizen's estimation that a given behaviour will lead to the desired personal outcome (e.g. cheaper services, lower cost), as Layne and Lee [4] stated, associated with that citizen's positive feelings about prior e-government service experiences, the citizen's intention to continue using e-government services will be reinforced. In sum, it is a learning process that could be shaped by the time needed to ensure that what is invested is fully utilised, and without continuity, e-government transformation will be difficult to realize. Yet, e-government, as an ICT-based technology, must be an up-to-date project 
that deals with the changes in technology usage, which is evolving rapidly; it could be difficult for citizens to cope with these changes without the requisite skills and experience. The value that e-government can bring to citizens could act as an incentive (or external motivator) for them to improve their personal capabilities in order to exploit the services in their own interest; as the system is being used, decision makers can make sure that the system is being utilised in the correct way.

\section{Conclusion}

The aim of this study is develop a model to examine the factors affecting egovernment continuity, satisfaction and expectation from citizens' perspectives. The model presents the relationships between the three major contexts (citizen, society and organization) with respect to the pre- and post-adoption process. The citizen's impact factor refers to previous experience and self-efficacy, and then to the resultant personal outcome expectations of the whole process (within cognitive techniques). The organizational context refers to the approach of incorporating two related models (IS Success and E-S-QUAL). By synthesizing the potential relationship constructs distributed among several models through classifying them into categories, the developed model examines the three main categories of the IS success model (system, which is synthesised from E-S-QUAL, and information and services). This is aimed at aligning the related actors within the nearest constructs. The UTAUT and E-S-QUAL features are mostly applicable to those three categories. This study has emphasized the satisfaction factor not only with reference to any increase in service quality but also to the capability of the citizens. Hence, for e-government practice, aligning the services offered with the capacity of the end-user is crucial and, as a result, it will facilitate the expansion of e-government in the future. Continuing to use the system implicitly implies a level of mutual trust among the relevant stakeholders, specifically citizens and government.

\section{References}

[1] Heeks, R., Bailur, S.: Analyzing E-Government Research. Perspectives, philosophies, theories, methods, and practice. Government Information Quarterly 24(2), 243-265 (2007)

[2] Bandura, A.: Social Foundations of Thought and Action: A Social Cognitive Theory. Prentice-Hall, Englewood Cliffs (1986)

[3] Bandura, A.: Social Cognitive Theory: An Agentic Perspective. Annual Review of Psychology 52(1), 1-26 (2001)

[4] Layne, K., Lee, J.W.: Developing Fully Functional E-government: A four stage model. Government Information Quarterly 18(2), 122-136 (2001)

[5] Carter, L., Weerakkody, V.: E-Government Adoption: A cultural comparison. Information Systems Frontiers 10(4), 473-482 (2008)

[6] Jasperson, J., Carter, P.E., Zmud, R.W.: A comprehensive conceptualization of postadoptive behaviours associated with information technology enabled work systems. MIS Quarterly 29(3), 525-555 (2005) 
[7] Compeau, D.R., Higgins, C.A.: Computer self-efficacy: development of a measure and initial test. MIS Quarterly 19(2), 189-211 (1995b)

[8] Hsu, M.H., Chiu, C.M., Ju, T.L.: Determinants of continued use of the WWW: an integration of two theoretical models. Industrial Management \& Data Systems 104(8-9), 766-775 (2004)

[9] Lim, E.T.K., Pan, S.L., Tan, C.W.: Managing user acceptance towards enterprise resource planning (ERP) systems - understanding the dissonance between user expectations and managerial policies. European Journal of Information Systems 14(2), 135-149 (2005)

[10] Gilbert, D., Balestrini, P.: Barriers and benefits in the adoption of e-government. The International Journal of Public Sector Management 17(4), 286-301 (2004)

[11] Coiera, E.: Interaction design theory. International Journal of Medical Informatics 69(23), 205-222 (2003)

[12] Brown, S.A., Massey, A.P., Montoya-Weiss, M.M., Burkman, J.R.: Do I really have to? User acceptance of mandated technology. European Journal of Information System 11(4), 283-295 (2002)

[13] Brown, S.A., Venkatesh, V., Kuruzovich, J., Massey, A.P.: Expectation confirmation: An examination of three competing models. Organizational Behavior and Human Decision Processes 105(1), 52-66 (2008)

[14] Chan, F.K.Y., Thong, J.Y.L., Venkatesh, V., Brown, S.A., Hu, P.J.H., Tam, K.Y.: Modeling Citizen Satisfaction with Mandatory Adoption of an E-Government Technology. Journal of the Association for Information Systems 11(10), 519-549 (2010)

[15] Venkatesh, V., Thong, J.Y.L., Chan, F.K.Y., Hu, P.J., Brown, S.A.: Extending the twostage information systems continuance model: incorporating UTAUT predictors and the role of context. Information Systems Journal 21, 527-555 (2011)

[16] DeLone, W.H., McLean, E.R.: The DeLone and McLean Model of Information Systems Success: A Ten-Year Update. Journal of Management Information Systems 19(4), 9-30 (2003)

[17] Chircu, A.M., Lee, D.H.-D.: E-government: Key Success Factors for Value Discovery and Realisation. E-Government, an International Journal 2(1), 11-25 (2005)

[18] Dwivedi, Y., Irani, Z.: Understanding the Adopters and Non-adopters of Broadband. Communications of the ACM 52(1), 122-125 (2009)

[19] Venkatesh, V., Morris, M., Davis, G., Davis, F.: User Acceptance of Information Technology: Toward a Unified View. MIS Quarterly 27(3), 425-478 (2003)

[20] Bandura, A.: Self-efficacy: Toward a unifying theory of behavioural change. Psychological Review 84, 191-215 (1977)

[21] Bandura, A.: Reflections on Self-efficacy. Advanced in Behavioural Research and Therapy 1, 237-269 (1978)

[22] Bandura, A.: Self-efficacy mechanism in human agency. American Psychology 372, 122 147 (1982)

[23] Zeithaml, V.A.: Consumer perceptions of price, quality, and value: a means end model and synthesis of evidence. Journal of Marketing 52(3), 2-22 (1988)

[24] Bhattacherjee, A.: Understanding information systems continuance: an expectation confirmation model. MIS Quarterly 25(3), 351-370 (2001a)

[25] Hung, S.Y., Chang, C.M., Yu, T.J.: Determinants of user acceptance of the e-government services: the case of online tax filing and payment system. Government Information Quarterly 23(1), 97-122 (2006)

[26] Zhang, P., von Dran, G.M.: Satisfiers and dissatisfiers: A two-factor model for Web site design and evaluation. Journal of the American Society for Information Science 51(14), 1253-1268 (2000) 
[27] West, D.M.: E-Government and the transformation of service delivery and citizen attitudes. Public Administration Review 64(1), 15-27 (2004)

[28] Moon, M.J.: The Evolution of E-Government among Municipalities: Rhetoric or Reality? Public Administration Review 62(4), 424-433 (2002)

[29] Shneiderman, B.: Universal usability. Communications of the ACM 43(5), 85-91 (2000)

[30] Zahedi, M.F., van Pelt, W.V., Song, J.: A conceptual framework for international Web design. IEEE Transactions on Professional Communication 44(2), 83-103 (2001)

[31] Kotler, P., Wong, V., Saunders, J., Armstrong, A.: Principles of Marketing, 4th edn. Pearson Education, England (2005)

[32] Reffat, R.: Developing A Successful E-Government, Working Paper, School Of Architecture. Design Science And Planning. University of Sydney, Australia (2003)

[33] Rogers, E.M.: Diffusion of Innovations, 4th edn. The Free Press, New York (1995)

[34] Davis, F.D.: Percieved usefulness, perceived ease of use and user acceptance of information technology 2. MIS Quarterly 13(3), 318-339 (1989)

[35] Ajzen, I., Fishbein, M.: Attitude-Behavior Relations: A Theoretical Analysis and Review of Empirical Research. Psychological Bulletin 84, 888-918 (1977)

[36] Moore, G., Benbasat, I.: Development of an instrument to measure the perceptions ofadopting an information technology innovation. Information Systems Research 2, 192 $222(1991)$

[37] Malhotra, Y., Galletta, D.F.: Extending the technology acceptance model to account for social influence: theoretical bases and empirical validation. Paper Presented at the 32nd Annual Hawaii International Conference on System Sciences, Hawaii (1999)

[38] Venkatesh, V., Davis, F.D.: A Theoretical Extension of the Technology Acceptance Model: Four Longitudinal Field Studie. Management Science 46(2), 186-205 (2000)

[39] Venkatesh, V., Morris, M.G.: Why don't men ever stop to ask for directions? Gender, social influence, and their role in technology acceptance and usage behaviour. MISQuarterly 24(1), 115-139 (2000)

[40] Lee, Y., Lee, J., Lee, K.: Social influence on technology acceptance behavior:self-identity theory perspective. The Database for Advances in Information Systems 37(2\&3), 60-75 (2006)

[41] Fishbein, M., Ajzen, I.: Belief, Attitude, Intention and Behaviour: An Introduction to Theory and Research. Addison-Wesley, Reading (1975)

[42] Parasuraman, A., Zeithaml, V.A., Malhotra, A.: E-SQUAL: multiple-item scale for assessing electronic service quality. Journal of Service Research 7(3), 213-234 (2005)

[43] Venkatesh, V., Davis, F.D., Morris, M.G.: Dead or alive? The development, trajectory and future of technology adoption research. Journal of the Association for Information Systems 8(4), 267-286 (2007)

[44] Davis, F.D., Bagozzi, R.P., Warshaw, P.R.: User acceptance of computer technology: A comparison of two theoretical models. Management Science 35(8), 982-1003 (1989)

[45] Taylor, S., Todd, P.A., Assessing, I.T.: Usage: The Role of Prior Experience. MIS Quarterly 19(4), 561-570 (1995a)

[46] Taylor, S., Todd, P.A.: Understanding Information Technology Usage: A Test of Competing Models. Information Systems Research 6(2), 144-176 (1995b)

[47] Bhattacherjee, A., Premkumar, G.: Understanding changes in belief and attitude toward information technology usage: A theoretical model and longitudinal test. MIS Quarterly 28(2), 229-254 (2004)

[48] Bhattacherjee, A.: An empirical analysis of the antecedents of electronic commerce service continuance. Decision Support Systems 32(2), 201-214 (2001b) 
[49] Hung, M.-C., Chang, I., Hwang, H.: Exploring academic teachers' continuance toward the web-based learning systems: The role of casual attributions. Computer \& Education 57(2), 1530-1543 (2011)

[50] Oliver, R.L.: A Cognitive Model for the Antecedents and Consequences of Satisfaction. Journal of Marketing Research 17, 460-469 (1980)

[51] Anderson, E.W., Sullivan, M.W.: The antecedents and consequences of customer satisfaction for firms. Marketing Science 12(2), 125-143 (1993)

[52] Compeau, D.R., Higgins, C.A.: Application of social cognitive theory for computer skills. Information Systems Research 6(2), 118-143 (1995a)

[53] Johnson, R.D., Marakas, G.M.: Research report: The role of behavioral modelling in computer skills acquisition - Toward refinement of the model. Information Systems Research 11(4), 402-417 (2000)

[54] Verdegem, P., Stragier, J., Verleye, G.: Measuring for Knowledge: A Data-Driven Research Approach for eGovernment. In: Proceedings of the 10th European Conference on E-government, pp. 417-424 (2010)

[55] Scholl, R.W.: Differentiating organizational commitment from expectancy as a motivating force. Academy of Management Review 6(4), 589-599 (1981)

[56] Wasko, M.M., Faraj, S.: Why should I share? Examining social capital and knowledge contribution in electronic networks of practice. MIS Quarterly 29(1), 35-57 (2005)

[57] Carter, L., Bélanger, F.: The utilization of e-government services: citizen trust,innovation and acceptance factors. Information Systems Journal 15(1), 5-25 (2005)

[58] Rogers, E.M.: Diffusion of Innovations, 3rd edn. The Free Press, New York (1983)

[59] Zeithaml, V.A., Berry, L.L., Parasuraman, A.: The behavioural consequences of service quality. Journal of Marketing 60(2), 31-46 (1996)

[60] Parasuraman, S., Zeithaml, V.A., Berry, L.L.: SERVQUAL: a multiple-item scale for measuring consumer perceptions of service quality. Journal of Retailing 64(1), 12-40 (1988)

[61] DeLone, W.H., McLean, E.R.: Information system success: The quest for dependent variable. Information Systems Research 3(1), 60-95 (1992)

[62] Parasuraman, S., Zeithaml, V.A., Berry, L.L.: A Conceptual Model of Service Quality and Its Implications for Future Research. Journal of Marketing 49, 41-50 (1985)

[63] Bandura, A.: Social cognitive theory of mass communication. In: Bryant, J., Oliver, M.B. (eds.) Media Effects: Advances in Theory and Research, 2nd edn., Mahwah, NJ, pp. 94-124 (2009) 